\title{
The Influence of Demographic Structure on Housing Price: An Empirical Analysis of Chongqing
}

\author{
Binghua Gao, Xinran He \\ College of Economics and Business Administration, Central China Normal University, Wuhan, China \\ Email: 279422559@qq.com
}

Received 29 March 2014; revised 30 April 2014; accepted 10 May 2014

Copyright (C) 2014 by authors and Scientific Research Publishing Inc. This work is licensed under the Creative Commons Attribution International License (CC BY). http://creativecommons.org/licenses/by/4.0/ (c) $\underset{\mathrm{EY}}{0}$ Open Access

\begin{abstract}
Residential housing price affects life of tens of thousands of families. Based on the relevant data of Chongqing's reports from 2003 to 2012, this paper studies the influence of population structure on residential housing price from the perspective of demand comprehensively. It comes up with the report that the population bring-up ratio and sex ratio have a negative influence on housing price, while sex ratio's influence is much bigger than the population bring-up ratio. In a word, the demographic structure will cause certain influence to the residential housing price of Chongqing.
\end{abstract}

\section{Keywords}

Demographics, Imbalanced Sex Ratio, Housing Price, Empirical Study

\section{Introduction}

In recent years, the national people of China pay a closer attention to the housing price with China's overall rising housing price. The Chinese government has promulgated several policies of macro regulation and control these years, but the effects are not obvious, and the housing price is increasing day by day. The main reason of this phenomenon is that the macro policies are focusing on the adjustment of the supply level. From the perspective of the demand, increasing population will inevitably lead to the increasing demand of housing [1]. In common sense, young and middle-aged people have the strongest purchasing power because they are in the prime of their life and the salary is the highest in their life. The more young and middle-aged people, the greater demand in housing market. According to TATISTICAL YEARBOOK OF CHINA, the proportion of workforce in China is bigger and we consider that the young and middle-aged people are increasing [2]. The newly-married people want to buy their own houses in general. With the young and middle-aged people going into the marriage market, 
the desire for housing will be stronger.

At the same time, the sex ratio in our country is continuously rising. Along with the sex ratio becoming more and more imbalanced, the possibility of a male having a nice marriage will be more difficult. Fewer females in the female-supply market will inevitably lead to a more intense competition in male-supply market. In general, females in the process of finding a male partner think about a lot especially the following two aspects: good moral character and wealth. It is more difficult to observe a good moral character; therefore, housing ownership is more intuitive to show a male's wealth. In order to stand out in the marriage market, the male and his family will do their best to save money to buy a house. In this way, with the continued imbalance of sex ratio, the demand of housing will increase.

This paper will make an empirical analysis and test based on the data of Chongqing city, in order to make out how the demographic structure affects the housing price.

\section{Literature Review}

The basic view of Shangjin Wei and Xiaobo Zhang (2011) [3] is, due to less male than female in China, gender imbalance led to that the male and their family will try their best to save money to buy a house, which improving the savings rates, bidding up housing price. Mankiw and Weil (1989) [4] proved that the change of population age structure is the main reason which led to the rapidly rising prices in the 20th century of the United States. Poterb (1991) [5] thought that demographic factors can indeed affect residential demand and then will affect housing price, but there is an objection on that when these effects to take effect. Poterba and Engelhardt et al. (1991) [6] based on Canadian data and found that the relationship between the population age and the demand for housing are as the same as what Mankiw and Wei had gotten.

The gender imbalances finally have an influence on marriage market imbalance, which involved a concept of demography: marriage squeeze. Zhigang Guo and Guosheng Geng (2000) [7] introduced the concept of marriage squeeze. In the condition of monogamy, because for the imbalance between supply and demand in the marriage market, namely the selection of male has a large difficulties to the selection of female in the marriage market, and ratio imbalance, will lead to a different spouse standard proportion from the traditional preference, and the marriage behavior changed greatly, this phenomenon is called marriage squeeze. Shuzhuo Li (2006) [8] made a conclusion that there is about 1.2 million male per year on average can not find female to get marriage in the marriage market. Jinhong Pan (2007) [9] had a research and showed that with the wide and continued gender imbalance, the marriage squeeze of male will lead to social problems.

\section{Basic Assumptions}

This paper is based on the perspective of population age and sex ratio and refers to the conclusion of scholars researches, get forward to the fallowing two assumptions:

\subsection{With the Increasing Population of Young and Middle-Aged People, the Housing Price Keeps Rising Up}

Young and middle-aged people have the strongest desire to buy houses in the marriage market, because after getting married they will start a new life in their dwelling places. If the young and middle-aged people are increasing in the population age structure, this shows that the young and middle-aged people in the marriage market are also increasing. It is likely to lead to the increasing demand of the residential market.

\subsection{The Imbalance of Sex Ratio Leads to the Rising of Housing Price}

Assume that in the case of more male than female, in order to set up a new family, the male will do all they can to highlight their advantages, and wealth is often to be a very important indicator, so the male and their families will do their best to save money to buy houses. In the social environment of "no house no marriage", the imbalance of sex ratio will rise the housing prices.

\section{Econometric Model and Regression Analysis}

\subsection{Variate Select}

This paper choose the Chongqing local GDP, Chongqing local GDR, Chongqing local sex ratio as explanatory 
variables, Chongqing housing prices as explained variable, make a regression analysis.

Explanatory variable P: Chongqing residential commodity house average sales price. This part of data comes from the People's Republic of China, a division of the national bureau of statistics website data.

Explained variable GDP: Chongqing local GDP. This part of data comes from the TATISTICAL YEARBOOK OF CHINA (2003-2012). A regional housing price is constitute an important source of local GDP, so local GDP is a persuasive explained variable.

Explained variable GDR: Chongqing local GDR. This part of data comes from the TATISTICAL YEARBOOK OF CHINA (2003-2012), and refer to the Chongqing local chronicles. GDR refers to the non-working age population divide the working age population, and the ratio is GDR. GDR is usually expressed as a percentage. GDR explains per 100 working age population need to burden of the number of the non-working age population. This paper according to TATISTICAL YEARBOOK OF CHINA, the age of people during age 15 to age 64 as the working age population, the age of people during age 0 to age 14 and over age 65 as the non-working age population.

Explained variable sex ratio: Chongqing local sex ratio. This part of data comes from the TATISTICAL YEARBOOK OF CHINA (2003-2012), and refer to the Chongqing local chronicles. Sex ratio is the ratio of the number of male and the number of female. According to the national bureau of statistics (NBS) standard, the sex ratio in women $=100$ as the standard.

In this paper, in order to eliminate the influence of inflation, when dealing with the data of each year, appointing 2003 as the basic period, using Chongqing residential commodity house average sales price and the Chongqing local GDR divide the Consumer Price Index (CPI) of each year. Finally, we use the processing data (Table 1) to make regression analysis.

\subsection{Model of Regression Analysis}

In order to solve the self-correlation, make 1-st difference to explanatory variable P, make 2-nd difference to explained variable GDP, the data of explained variable GDR and explained variable sex ratio are stable [10].

Establish a linear regression equation of DP with D2GDP, GDR, sex ratio, following is the regression equation:

$$
\mathrm{DP}=\mathrm{C}+\partial_{1} \mathrm{D} 2 \mathrm{GDP}+\partial_{2} \mathrm{GDP}+\partial_{3} \text { sex ratio }+\xi
$$

Through the EVIEWS 6.0, the following are the regression results:

\begin{tabular}{|c|c|c|c|c|}
\hline $\begin{array}{l}\text { Dependent Variable } \\
\text { Method: Least Squa } \\
\text { Date: } 03 / 29 / 14 \\
\text { Sample (adjusted): } \\
\text { Included observatio }\end{array}$ & $\begin{array}{l}1 \\
2 \\
\text { r adjustment }\end{array}$ & & & \\
\hline Variable & Coefficient & Std. Error & $\mathrm{t}$-Statistic & Prob. \\
\hline C & 147465.0 & 47453.04 & 3.107599 & 0.0360 \\
\hline D2GDP & 0.844123 & 0.226638 & 3.7246547 & 0.0204 \\
\hline GDR & -670.0835 & 158.5658 & -4.225901 & 0.0134 \\
\hline SEXRATIO & -1129.744 & 430.6768 & -2.623182 & 0.0586 \\
\hline R-squared & 0.868478 & \multicolumn{2}{|c|}{ Mean dependent var } & 3628.086 \\
\hline Adjusted R-squared & 0.769836 & & 1864.930 \\
\hline S.E. of regression & 894.7079 & \multicolumn{2}{|c|}{ Akaike info criterion } & 16.73772 \\
\hline Sum squared resid & 3202009 & \multicolumn{2}{|c|}{ Schwarz criterion } & 16.77745 \\
\hline Log likelihood & -62.95090 & \multirow{2}{*}{\multicolumn{2}{|c|}{$\begin{array}{l}\text { Hannan-Quinn criter. } \\
\text { Durbin-Watson stat }\end{array}$}} & 16.46982 \\
\hline F-statistic & 8.804364 & & & 1.940666 \\
\hline Prob(F-statistic) & 0.030975 & & & \\
\hline
\end{tabular}

Regression results analysis: 1 ) R-squared is 0.868478 , adjusted R-squared is 0.769836 , both are very close to 1 , indicate that the regression model is highly significant; 2) F-statistic is 8.804364, Prob (F-statistic) $=0.030975<$ 0.05 , the $F$ test result shows that the equations which have been established are efficacious; 3) except ex- 
Table 1. Chongqing residential commercial housing price factors.

\begin{tabular}{ccccc}
\hline Year & P (yuan/square meters) & GDP (billion/year) & GDR & Sex ratio \\
\hline 2003 & 1324 & 7209 & 38.89 & 103.56 \\
2004 & 1531 & 9358 & 47.75 & 99.3 \\
2005 & 1889 & 10917 & 46.27 & 101.57 \\
2006 & 2075 & 12420 & 44.72 & 102.56 \\
2007 & 2499 & 14156 & 44.11 & 102.56 \\
2008 & 2522 & 19580 & 44.87 & 101.7 \\
2009 & 3328 & 23358 & 42.78 & 100.66 \\
2010 & 3957 & 27034 & 39.94 & 102.4 \\
2011 & 4313 & 33125 & 39.78 & 104 \\
2012 & 4739 & 38383 & 41.5 & 101.37 \\
\hline
\end{tabular}

plained variable sex ratio, the explanatory variables in the regression model pass $\mathrm{T}$ test, is highly significant, and the prob of explained variable sex ratio is close to 0.05 ; 4) Durbin-Watson stat is 1.940666 , very close to 2 , there is no serial correlation in this regression model [11].

Generally speaking, regression model results are good.

After heteroscedasticity test of white test, available regression results are as follows:

Heteroskedasticity Test: White

\begin{tabular}{llll}
\hline \hline F-statistic & 2.378413 & Prob. F(3,4) & 0.2107 \\
Obs*R-squared & 5.126240 & Prob. Chi-Square(3) & 0.1628 \\
Scaled explained SS & 0.916883 & Prob. Chi-Square(3) & 0.8214 \\
\hline \hline
\end{tabular}

Regression results analysis: in the above table, Obs*R-squared is $L M=n \times R^{2}$, and the ending prob is greater than the significance level of $0.1,0.005$ or 0.001 , accept the null hypothesis, there is no heteroscedasticity residuals.

So we can draw the conclusion that there is neither the multicollinearity exists nor heteroscedasticity residuals phenomena in the regression model.

The regression model results:

DP $=147465.046661+0.844123414246 *$ D2GDP $-670.083461717 *$ GDR $-1129.74351843 *$ sex ratio.

From the regression results, Chongqing local GDP has a positive correlation to Chongqing residential commodity house average sales price, but Chongqing local GDR and Chongqing local sex ratio have a negative correlation to Chongqing residential commodity house average sales price. Therefore, the results overthrow the two basic assumptions in this paper: the increasing population of young and middle-aged will rise up housing price and the imbalance of sex ratio lead to the rising of housing price.

\section{Conclusion}

Residential property prices affect the interests of tens of thousands of families. In this paper, according to the regression analysis, the young and middle-aged people will not increase the housing price although they need a house to get marriage, and marriage market gender imbalance will not make a positive influence on housing price. Different from the majority of the articles which discuss a single impact from the view point of age or gender structure behind housing prices, this paper is based on the data of Chongqing from 2003 to 2012, and makes a comprehensive consideration of the influence of demographic structure on housing price. The results show that demographic structure has a negative correlation on housing price. 


\section{References}

[1] Feng, L., Lin, Z.-J. and Lv, P. (2008) Real Estate Economics. 3rd Edition, China Architecture \& Building Press, Beijing.

[2] Lu, Y. and Zhai, Z.-W. (2009) Sixty Years of New China Population. China Population Publishing House, Beijing.

[3] Wei, S.-J. and Zhang, X.-B. (2011) The Competitive Saving Motive: Evidence from Rising Sex Ratios and Savings Rates in China. Journal of Political Economy, 119, 511-564. http://dx.doi.org/10.1086/660887

[4] McFadden, D. (1990) Demographics, the Housing Market, and the Welfare of the Elderly: A Preliminary Report on Proposed Research. Unpublished Paper, Massachusetts Institute of Technology.

[5] Poterba, J.M. (1991) House Price Dynamics: The Role of Tax Policy and Demography. Brookings Paper on Economic Activity, 2, 143-203. http://dx.doi.org/10.2307/2534591

[6] Engelhardt, G.V. and Poterba, J.M. (1991) House Prices and Demographic Change: Canadian Evidence. Regional Science and Urban Economics, 21, 539-546. http://dx.doi.org/10.1016/0166-0462(91)90017-H

[7] Guo, Z.-G. and Deng, G.-S. (2000) Study on Marriage Squeeze in China. Market \& Demographic Analysis, 5.

[8] Li, S.-Z., Jiang, Q.-B., Attane, I. and Feldman, M.W. (2006) Son Preference and the Marriage Squeeze in China: An Integrated Analysis of the First Marriage and Remarriage Market. Population \& Economics, 4.

[9] Chui, S.-T. (2010) Urban Housing Price Influence Factors Analysis-In Shanghai, for Example. Shaanxi Journal of Agricultural Sciences, 3.

[10] Wooldridge, J.M. (2010) Intiductory Econometrics. 4th Edition, China Renmin University Press, Beijing.

[11] Luo, Y. (2012) Embedded in the Field of Urban Youth Housing Extrusion Phenomenon Research—In Three Cities of Jiangsu Province as an Example. Master Degree Theses of Master of Nanjing University, Nanjing. 